\title{
MORFOMETRI BEBERAPA VARIETAS TANAMAN PADI (Oryza sativa L.) DI KECAMATAN PULAU RIMAU BANYUASIN
}

\author{
Tedy Sigit Purwansyah ${ }^{1 *}$, Dewi Rosanti ${ }^{2}$, Trimin Kartika ${ }^{3}$ \\ ${ }^{1,2,3}$ Program Studi Biologi Fakultas Sains dan Teknologi \\ Universitas PGRI Palembang \\ *e-mail: tedysigitpurwansyah01@ gmail.com
}

\begin{abstract}
This study aims to study the morphometry of several varieties of rice (Oryza sativa L.) in Pulau Rimau Subdistrict, Banyusin Regency, which was carried out from March to June 2021. The method used was the observation method (direct observation in the field), sampling was carried out by purposive sampling in one plot. rice crop area in each rice variety area. The results showed that the rice root system was fibrous, the average number of root branches in one stem of rice varieties ranged from 41 80 root branches. The stem has similarities in the shape of the stem, which is round, on average stem segments ranging from 4 - 6 segments per stem with an average stem height ranging from $59.8-106.2$ $\mathrm{cm}$, average stem diameter ranging from $0.54 \mathrm{~mm}-0.74 \mathrm{~mm}$. The leaves have a circum scriptio in the form of a green ribbon with an average number of leaves ranging from 4-6 strands, the average leaf length ranging from $31.5 \mathrm{~cm}-55.1 \mathrm{~cm}$, rough leaf surface, flat leaf edge, tapered leaf tip and leaf veins parallel. The number of panicles is 1 per stem, with the average panicle length ranging from $21.1-30$ $\mathrm{cm}$, and the average fruit per panicle ranging from $87-218$ pieces. The fruit is long slender, slender, medium long, medium, to short slender, clean yellow to grayish black, with an average diameter of 25 - $28 \mathrm{~mm}$, an average length of $7.9-10.3 \mathrm{~mm}$, and the average fruit weight is $1.11-1.49$ grams.
\end{abstract}

Keywords: Oryza sativa, Morphometry, Varieties.

\begin{abstract}
ABSTRAK
Penelitian bertujuan untuk mengkaji morfometri beberapa varietas tanaman padi (Oryza sativa L.) di Kecamatan Pulau Rimau Kabupaten Banyusin telah dilakukan dari Bulan Maret sampai Juni 2021. Metode yang dilakukan adalah metode observasi (pengamatan langsung ke lapangan), pengambilan sampel dilakukan secara Purposive Sampling pada satu petak areal tanaman padi di setiap areal varietas padi. Hasil penelitian menunjukkan bahwa sistem perakaran padi adalah serabut, rata-rata jumlah cabang akar dalam satu batang varietas tanaman padi berkisar 41 - 80 cabang akar. Batang terdapat persamaan pada bentuk batang yaitu berbentuk bulat, pada rata-rata ruas batang berkisar 4 - 6 ruas per-batang dengan rata-rata tinggi batang berkisar 59,8 $-106,2 \mathrm{~cm}$, rata-rata diameter batang berkisar 0,54 $\mathrm{mm}-0,74 \mathrm{~mm}$. Daun memiliki circum scriptio berbentuk pita berwarna hijau dengan rata-rata jumlah daun berkisar $4-6$ helai, rata-rata panjang daun berkisar $31,5 \mathrm{~cm}-55,1 \mathrm{~cm}$, permukaan daun kasar, tepi daun rata, ujung daun meruncing dan pertulangan daun sejajar. Malai berjumlah 1 per-batang, dengan rata-rata panjang malai berkisar $21,1-30 \mathrm{~cm}$, dan rata-rata buah permalai berkisar 87 - 218 buah. Buah berbentuk ramping panjang, ramping, sedang panjang, sedang, sampai ramping pendek, berwarna kuning bersih hingga berwarna hitam keabu-abuan, dengan rata-rata diameter 25 - $28 \mathrm{~mm}$, rata-rata panjang 7,9 - 10,3 mm, dan rata-rata berat buah 1,11 - 1,49 gram.
\end{abstract}

Kata kunci : Oryza sativa, Morfometri, Varietas

E IISN: 2655-9137 


\section{Morfometri Beberapa Varietas Tanaman.., Tedy Sigit Purwansyah, Dewi Rosanti, Trimin Kartika,}

Indobiosains, Volume 3 No. 2, Agustus 2021, 28-38

\section{PENDAHULUAN}

Indonesia dikenal negara agraris. Mayoritas penduduk bekerja disektor pertanian, dengan hasil utama beras. Sektor pertanian merupakan sektor primer dan memegang peranan penting bagi perekonomian nasional. Hal ini karena negara Indonesia beriklim tropis serta ditunjang dengan kondisi tanah yang baik untuk digunakan bercocok tanam (Zaeroni dan Rustariyuni, 2016). Selain itu menurut Sutrisna dan Dewi (2016), sektor pertanian juga sangat berpeluang dalam meningkatkan perekonomian Indonesia.

Sumatera Selatan merupakan salah satu lumbung pangan di Indonesia dengan tingkat produksi padi (angka tetap) mencapai 577,49 ton pada tahun 2015, Peningkatan produksi padi meningkat seiring bertambahnya areal pertanian. Penghasil padi terbesar di Sumatera Selatan salah satunya Kabupaten Banyuasin. Pada tahun 2015 Kabupaten Banyuasin menghasilkan produksi padi terbesar di Sumatera Selatan, dan berikutnya Kabupaten Ogan Komering Ulu Timur dan Kabupaten Ogan Komering Ilir, sedangkan produksi padi yang terendah itu dihasilkan dari Kota Prabumulih (Badan Pusat Statistik , 2015).

Padi termasuk pada genus Oryza yang meliputi lebih kurang 25 spesies. Sekarang terdapat dua species tanaman padi yang dibudidayakan yaitu Oryza sativa L. dan Oryza glaberrima Steud. Oryza sativa berkembang menjadi tiga sesuai dengan ekogeografisnya, yaitu Indica, Japonica, dan Javanica. Ada dua spesies padi yang dibudidayakan manusia secara massal hingga sekarang, Oryza sativa yang berasal dari Asia dan O.glaberrima yang berasal dari Afrika Barat. Pada awal mulanya O.sativa dianggap terdiri dari dua subspesies, indica dan japonica (sinonim sinica). Padi japonica umumnya berumur panjang, postur tinggi namun mudah rebah, lemma memiliki ekor atau bulu, bijinya cenderung membulat, dan nasinya lengket. Padi indica, sebaliknya, berumur lebih pendek, postur lebih kecil, lemma tidak berbulu atau hanya pendek saja, dan bulir cenderung oval sampai lonjong. Walaupun kedua anggota subspesies ini dapat saling membuahi, persentase keberhasilannya tidak tinggi. Hasil dari seleksi persilangan japonica dengan indica adalah kultivatur IR-8. Selain kedua varietas ini, dikenal varietas minor javanica yang memiliki sifat antara dari kedua tipe utama di atas. Varietas javanica hanya ditemukan di Pulau Jawa (Norsalis, 2011).

Morfologi tumbuhan merupakan cabang ilmu biologi yang mempelajari susunan dan bentuk luar suatu tumbuhan (Gani dan Arwita, 2020). Struktur pokok yang bisa diamati seperti bagian akar, daun, batang, bunga, buah dan struktur lain yang terbentuk dari metamorfosis tumbuhan (Rosanti, 2013). Kecamatan Pulau Rimau Kabupaten Banyuasin merupakan salah satu penghasil padi yang ada di Sumatera Selatan, dimana padi merupakan sumber mata pencaharian utama dari sebagian masyarakat setempat. Benih yang biasa digunakan para petani Kecamatan Pulau Rimau Kabupaten Banyuasin adalah varietas unggul maupun lokal yang berasal dari Pemerintah Dinas Pertanian dan Dinas Ketahanan Pangan Hortikultur Kabupaten Banyuasin.

Informasi tentang morfologi tanaman padi di Kecamatan Pulau Rimau Kabupaten Banyuasin masih sangat terbatas. Petani hanya melihat pada sisi produksi yang dihasilkan saja, tanpa memperhatikan morfologi setiap varietas 
Morfometri Beberapa Varietas Tanaman.., Tedy Sigit Purwansyah, Dewi Rosanti, Trimin Kartika, Indobiosains, Volume 3 No. 2, Agustus 2021, 28-38

padi. Peneliti tertarik untuk meneliti morfologi beberapa varietas padi yang biasa ditanam para petani di areal persawahan Kecamatan Pulau Rimau Kabupaten Banyuasin, untuk memberikan pengetahuan bagi petani dan mempermudah petani dalam membedakan antara satu varietas padi dengan varietas padi lainnya secara morfologi.

\section{BAHAN DAN METODE}

Penelitian telah dilaksanakan di bulan Maret sampai Juni 2021. Alat yang digunakan meliputi kamera ponsel, mistar, jangka sorong, timbangan analitik dan alat tulis. Sedangkan bahan yang digunakan adalah alcohol dan specimen tanaman padi dari varietas Ciherang, Cimelati, Ketan putih (Ciasem), IR 64, IR 42, Inpari 32 HDB, Mapan 05, dan Ketan hitam. Metode dilakukan dengan metode observasi (pengamatan langsung ke lapangan) di
Kecamatan Sumber Harta pada 4 desa yakni; Desa Dana Mulya, Sumber Mulya, Nunggal Sari dan Budi Asih. Data yang diperoleh dari hasil observasi merupakan data primer dan pengukuran terhadap 5 batang tanaman padi pada fase generatif. Pengambilan sampel dilakukan secara purposive sampling pada satu petak areal tanaman padi di setiap areal varietas padi.

\section{HASIL DAN PEMBAHASAN}

\section{Penyebaran Varietas Padi}

Dari hasil penelitian yang telah dilakukan di Kecamatan Pulau Rimau Kabupaten Banyuasin pada empat desa yang telah dipilih yaitu Desa Dana Mulya, Desa Sumber Mulya, Desa Nunggal Sari, Desa Budi Asih dapat diinformasikan bahwa delapan varietas padi tidak ditemukan merata pada empat desa tersebut. Adapun penyebaran delapan varietas padi tersebut disajikan pada Tabel 1 sebagai berikut:

Tabel 1. Penyebaran Varietas Padi di Kecamatan Pulau Rimau Kabupaten Banyuasin.

\begin{tabular}{llllll}
\hline \multirow{2}{*}{ No. } & Varietas Padi & \multicolumn{5}{c}{ Lokasi Ditemukan } \\
\cline { 3 - 6 } & & Dana Mulya & Sumber Mulya & Nungal Sari & Budi Asih \\
\hline 1. & Ciherang & - & $\sqrt{ }$ & $\sqrt{ }$ & - \\
2. & Cimelati & $\sqrt{ }$ & $\sqrt{ }$ & - & $\sqrt{ }$ \\
3. & Ciasem & $\sqrt{ }$ & - & - & - \\
4. & IR 64 & - & - & $\sqrt{ }$ & $\sqrt{ }$ \\
5. & IR 42 & $\sqrt{ }$ & - & $\sqrt{ }$ & - \\
6. & Inpari 32 HDB & $\sqrt{ }$ & $\sqrt{ }$ & $\sqrt{ }$ & $\sqrt{ }$ \\
7. & Mapan 05 & - & $\sqrt{ }$ & - & - \\
8. & Ketan Hitam & $\sqrt{ }$ & - & - & - \\
\hline
\end{tabular}

Keterangan: $\sqrt{ }=$ ditemukan, $-=$ tidak ditemukan.

Berdasarkan Tabel 1. varietas padi yang ditemukan di Kecamatan Pulau Rimau Kabupaten Banyuasin di desa Dana
Mulya terdapat 5 varietas yaitu varietas Cimelati, Ciasem, IR 42, Inpari $32 \mathrm{HDB}$, dan Ketan Hitam. Varietas padi yang 


\section{Morfometri Beberapa Varietas Tanaman.., Tedy Sigit Purwansyah, Dewi Rosanti, Trimin Kartika,}

Indobiosains, Volume 3 No. 2, Agustus 2021, 28-38

ditemukan di desa Sumber Mulya yaitu varietas padi Ciherang, Cimelati, Inpari 32 HDB, dan Mapan 05. Varietas padi yang ditemukan di desa Nunggal Sari yaitu Ciherang, IR 64, IR 42, Inpari 32 HDB, sedangkan varietas padi yang ditemukan di desa Budi Asih yaitu varietas Cimelati, IR 64, dan Inpari 32 HDB.

Dari delapan varietas padi yang ditemukan, padi varietas Inpari $32 \mathrm{HDB}$ yang terdapat pada keempat desa. Hal ini dikarenakan nilai ekonomis, varietas Inpari 32 HDB produksinya lebih tinggi, memiliki keunggulan tahan terhadap penyakit kresek, penyakit tugro, penyakit blos dan mempunyai umur masa panen yang relatif pendek, penanaman varietas Impari 32 HDB yang cukup pesat mulai menjadi primadona di lahan sawah irigasi sehingga petani lebih memilih varietas tersebut dibandingkan memilih jenis varietas lain. Hal ini sesuai dengan pendapat Badan Penelitian dan Pengembangan Pertanian (2017), dimana masa panen padi varietas Inpari 32 HDB hanya 120 hari setelah tanam.

Hasil penelitian Darwati dan Noeriwan (2019) varietas Inpari 32 HDB merupakan padi jenis baru yang sudah banyak diminati petani. Produktivitas padi Inpari 32 HDB menunjukkan adanya peningkatan hasil gabah kering panen padi berturut-turut sebesar $1.36 \mathrm{t} / \mathrm{ha}, 0.6 \mathrm{t} / \mathrm{ha}$ dan
0.77 t/ha dibanding padi varietas Ciherang. Varietas Inpari 32 HDB mempunyai potensi untuk dikembangkan di lahan sawah menggantikan varietas Ciherang. Tentunya dengan pendampingan teknologi yang dilakukan oleh BPTP dan Dinas Pertanian terkait.

Varietas padi yang paling sedikit ditanam adalah Ciasem, Mapan 05 dan Ketan hitam, dimana hanya ditanam masing-masing di satu Desa. Pada varietas padi ketan hanya terdapat di desa Dana Mulya, varietas Ciasem juga ditemukan hanya di Desa Dana Mulya ini dikarenakan varietas ketan bukan menjadi komoditas utama. Menurut Yandianto (2003) dalam Akmaliyanti (2008) padi ketan merupakan padi yang hasilnya bukan sebagai makanan pokok sehari-hari, padi ketan tidak dikonsumsi secara langsung sebagai makanan pokok. Sedangkan varietas Mapan 05 hanya ditemukan di Desa Sumber Mulya, hal ini disebabkan karena petani lebih memilih varietas yang sering ditanam seperti varietas Ciherang dan varietas jenis Inpari.

\section{Morfometri Varietas padi (Oryza sativa L.) Morfometri Akar}

Morfometri akar yang diamati adalah jumlah akar dan sistem perakaran. Hasil pengamatan morfometri akar ini disajikan dalam Tabel 2. sebagai berikut: 
Morfometri Beberapa Varietas Tanaman.., Tedy Sigit Purwansyah, Dewi Rosanti, Trimin Kartika, Indobiosains, Volume 3 No. 2, Agustus 2021, 28-38

Tabel 2. Pengamatan Morfometri Akar Pada Beberapa
\begin{tabular}{llll}
\multicolumn{4}{c}{ Varietas Tanaman Padi. } \\
\hline No. & Varietas & $\bar{X}$ CA & SP \\
\hline 1 & Ciherang & 63 & Serabut \\
2 & Cimelati & 63 & Serabut \\
3 & Ciasem & 80 & Serabut \\
4 & IR 64 & 43 & Serabut \\
5 & IR 42 & 44 & Serabut \\
6 & Inpari 32 HDB & 42 & Serabut \\
7 & Mapan 05 & 51 & Serabut \\
8 & Ketan Hitam & 41 & Serabut
\end{tabular}

Keterangan: $\bar{X} \mathbf{C A}=$ Rata-rata jumlah cabang akar; $\mathrm{SP}=$ Sistem perakaran.

Dari hasil pengamatan pada morfologi akar delapan varietas padi yang disajikan pada Tabel 2. di atas diketahui bahwa morfologi akar yang diamati memiliki sistem perakaran yang sama yaitu sistem perakaran serabut. Terdapat perbedaan pada rata-rata jumlah akar setiap varietas padi tersebut. Adapun rata-rata jumlah cabang akar yang tertinggi adalah varietas Ciasem dengan jumlah 80 cabang akar, sedangkan rata-rata jumlah cabang akar terendah pada varietas Ketan Hitam yaitu 41 cabang akar.

Morfometri akar pada varietas Ciherang dan varietas Cimelati memiliki rata-rata jumlah cabang akar yang sama yaitu63 cabang akar, varietas IR 64 memiliki rata-rata 43 jumlah cabang akar, varietas IR 42 memiliki rata-rata 44 jumlah cabang akar, varietas Inpari 32 HDB memiliki rata-rata 42 jumlah cabang akar, dan varietas Mapan 05 memiliki rata-rata 51 jumlah cabang akar. Jumlah rata-rata cabang akar didapat dengan menghitung cabang akar dalam satu varietas sebanyak lima individu, semakin tinggi dan besar diameter batang akan terbentuk jumlah cabang akar yang banyak. Hasil tersebut didukung oleh pernyataan bahwa pengamatan panjang dan jumlah serabut akar menunjukkan kemiripan dengan tinggi tanaman, fitohormon yang diproduksi Azospirillum menyebabkan perubahan morfologi akar setelah inokulasi dimana terjadi peningkatan densitas dan panjang rambut akar, perubahan akar lateral maupun area permukaan akar karena ada peningkatan serapan hara (Lestari et al., 2019). Lebih lanjut menurut Kesmayanti dan Mareza (2014) semakin sedikit cabang akar semakin sedikit kemampuan dalam penyerapan unsur hara oleh tanaman. Hal ini akan menyebabkan pertumbuhan tanaman terhambat, sehingga tanaman akan menjadi kerdil dan produktivitas menurun.

\section{Morfometri Batang}

Yang diamati dalam karakteristik morfometri batang yang dapat diamati adalah bentuk batang, diameter batang, tinggi batang, dan jumlah ruas per-batang. Hasil pengamatan morfologi batang disajikan dalam Tabel 3. sebagai berikut: 
Morfometri Beberapa Varietas Tanaman.., Tedy Sigit Purwansyah, Dewi Rosanti, Trimin Kartika, Indobiosains, Volume 3 No. 2, Agustus 2021, 28-38

Tabel 3. Pengamatan Morfometri Batang Pada Beberapa Varietas Tanaman Padi

\begin{tabular}{llllll}
\hline No. & Varietas & BBt & $\begin{array}{l}\bar{X} \text { DBt } \\
(\mathbf{c m})\end{array}$ & $\begin{array}{l}\bar{X} \text { TBt } \\
(\mathbf{c m})\end{array}$ & $\begin{array}{l}\text { RRBt } \\
\text { (ruas) }\end{array}$ \\
\hline 1. & Ciherang & Bulat & 0,62 & 65,6 & $4-5$ Ruas \\
2. & Cimelati & Bulat & 0,68 & 106,2 & 5-6 Ruas \\
3. & Ciasem & Bulat & 0,64 & 81,8 & $4-5$ Ruas \\
4. & IR 64 & Bulat & 0,64 & 68 & $4-5$ Ruas \\
5. & IR 42 & Bulat & 0,74 & 82,4 & $4-5$ Ruas \\
6. & Inpari 32 HDB & Bulat & 0,54 & 75,9 & $4-5$ Ruas \\
7. & Mapan 05 & Bulat & 0,62 & 69,4 & 5-6 Ruas \\
8. & Ketan Hitam & Bulat & 0,56 & 59,8 & $4-5$ Ruas \\
\hline
\end{tabular}

Keterangan: $\mathrm{BBt}=$ Bentuk batang; $\bar{X} \mathbf{D B t}=$ Rata-rata diameter batang; $\bar{X}$ TBt $=$ Rata-rata tinggi batang $(\mathrm{cm}) ; \mathrm{RRBt}=$ Rata-rata jumlah ruas dalam satu batang.

Pada Tabel 3. terlihat bahwa ada beberapa karakter morfologi batang yang menunjukan kesamaan di antara semua varietas yaitu kesamaan pada bentuk batang semua bulat. Karena padi memiliki jenis batang rumput (Calmus) dimana menurut Rosanti (2013), batang rumput dimiliki oleh familia poaceae termasuk padi. Batang rumput merupakan batang bulat dengan banyak ruas, panjang ruas tergolong pendek.

Diameter batang, ruas batang hampir semua berbeda hanya diameter batang varietas Ciasem dan IR 64 yang sama yaitu $0,64 \mathrm{~cm}$. Rata-rata diameter batang terbesar terdapat pada varietas IR 42 yaitu $0,74 \mathrm{~cm}$, sedangkan diameter batang terkecil pada varietas Inpari 32 HDB yaitu $0,54 \mathrm{~cm}$. Rata-rata tinggi batang tertinggi terdapat pada varietas Cimelati yaitu $106,2 \mathrm{~cm}$, sedangkan rata-rata tinggi batang terendah pada varietas Ketan hitam yaitu $59,8 \mathrm{~cm}$. Rata-rata jumlah ruas perbatang yang paling banyak terdapat pada varietas Cimelati dan varietas Mapan 05 yaitu 5 - 6 ruas.
Perbedaan diameter dan panjang batang setiap varietas itu tergantung dari faktor lingkungan dan sifat genetik masingmasing varietas. Hal ini diperkuat oleh Nursalis (2011), bahwa tinggi tanaman adalah suatu sifat baku (keturunan), adanya perbedaan tinggi dari suatu varietas disebabkan oleh suatu pengaruh keadaan lingkungan. Lahan sawah di Kecamatan Pulau Rimau umumnya dalam kondisi tergenang, sehingga tinggi tanaman sangat mempengaruhi produktivitas tanaman.

\section{Morfometri Daun}

Morfometri daun yang diamati pada penelitian ini adalah warna daun, jumlah rata-rata daun pada setiap batang varietas padi, bentuk daun, rata-rata panjang daun, permukaan daun, tepi daun, ujung daun, dan pertulangan daun. Morfologi daun menunjukkan keseragaman kecuali ratarata jumlah helai daun, dan rata-rata panjang daun. Adapun hasil dari pengamatan morfologi batang ini disajikan dalam Tabel 4. sebagai berikut 
Morfometri Beberapa Varietas Tanaman.., Tedy Sigit Purwansyah, Dewi Rosanti, Trimin Kartika, Indobiosains, Volume 3 No. 2, Agustus 2021, 28-38

Tabel 4. Morfometri Daun Dari Beberapa Varietas Tanaman Padi

\begin{tabular}{|c|c|c|c|c|c|c|c|c|c|}
\hline $\begin{array}{l}\text { No } \\
\text { - }\end{array}$ & $\begin{array}{l}\text { Nama } \\
\text { Varietas }\end{array}$ & WD & $\begin{array}{l}\text { RD/B } \\
\text { (Helai) }\end{array}$ & BD & $\begin{array}{l}\bar{X} \text { PD } \\
(\mathbf{C m})\end{array}$ & PD & TD & UD & PDn \\
\hline 1. & Ciherang & Hijau & 4-5 Helai & $\begin{array}{l}\text { Bangun } \\
\text { pita }\end{array}$ & 40,2 & Kas: & Rata & Meruncing & Sejajar \\
\hline 2. & Cimelati & Hijau & 5-6 Helai & $\begin{array}{l}\text { Bangun } \\
\text { pita }\end{array}$ & 39,7 & Kasar & Rata & Meruncing & Sejajar \\
\hline 3. & Ciasem & Hijau & 4-5 Helai & $\begin{array}{l}\text { Bangun } \\
\text { pita }\end{array}$ & 55,1 & Kasar & Rata & Meruncing & Sejajar \\
\hline 4. & IR 64 & Hijau & 4-5 Helai & $\begin{array}{l}\text { Bangun } \\
\text { Pita }\end{array}$ & 40 & Kasar & Rata & Meruncing & Sejajar \\
\hline 5. & IR 42 & Hijau & 4-5 Helai & $\begin{array}{l}\text { Bangun } \\
\text { pita }\end{array}$ & 54,7 & Kasar & Rata & Mer & Sejajar \\
\hline 6. & $\begin{array}{ll}\text { Inpari } & 32 \\
\text { HDB } & \end{array}$ & Hijau & 4-5 Helai & $\begin{array}{l}\text { Bangun } \\
\text { pita }\end{array}$ & 40,8 & Kasar & Rata & Meruncing & Sejajar \\
\hline 7. & Mapan 05 & Hijau & 5-6 Helai & $\begin{array}{l}\text { Bangun } \\
\text { Pita }\end{array}$ & 36,4 & Kasar & Rata & Meruncing & Sejajar \\
\hline 8. & $\begin{array}{l}\text { Ketan } \\
\text { Hitam }\end{array}$ & Hijau & 4-5 Helai & $\begin{array}{l}\text { Bangun } \\
\text { Pita }\end{array}$ & 31,5 & Kasar & Rata & Meruncing & Sejajar \\
\hline
\end{tabular}

Keterangan: $\mathrm{WD}=\mathrm{W}$ arna daun;RD/B (helai)= Rata-rata jumlah daun per-batang; $\mathrm{BD}=$ bentuk daun;

$\bar{X} \mathrm{PD}(\mathrm{cm})=$ Rata-rata panjang daun; $\mathrm{PD}=$ Permukaan daun; $\mathrm{TD}=$ Tepi daun; $\mathrm{UD}=$ Ujung daun; PDn= Pertulangan daun.

Dari hasil penelitian morfologi daun pada delapan varietas padi yang ditemukan didapat bahwa morfologi daun pada delapan varietas padi memiliki kesamaan yakni pada warna daun berwarna hijau, Circum scripto berbentuk bangun pita, permukaan daun kasar, tepi daun (margo folii) rata, ujung daun meruncing, pertulangan daun (Nervatio) sejajar. Perbedaan pada setiap varietas tanaman padi. Nilai rata-rata panjang daun yang paling tinggi adalah varietas Ciasem $(55,1$ $\mathrm{cm})$ dibandingkan dengan varietas lainnya, sedangkan nilai rata-rata panjang daun yang terendah adalah varietas Ketan hitam yaitu $31,5 \mathrm{~cm}$. Varietas Cimelati dan Mapan 05 memiliki rata-rata jumlah helai daun yang paling banyak yaitu 5-6 helai sedangkan varietas lainnya memiliki ratarata jumlah helai daun perbatangnya 4-5 helai.
Morfometri daun varietas Ciherang diperoleh data bahwa rata-rata helai daun 4-5 helai per-batang, rata-rata panjang daun $40,2 \mathrm{~cm}$, daun berwarna hijau tua, daun berbentuk bangun pita, permukaan daun kasar, tepi daun rata dan ujung daun meruncing serta memiliki pertulangan daun sejajar. Morfometri pada varietas Cimelati diperoleh data bahwa rata-rata helai daun 5-6 helai per-batang, rata-rata panjang daun $39,7 \mathrm{~cm}$, daun berwarna hijau, daun berbentuk bangun pita, permukaan daun kasar, tepi daun rata dan ujung daun meruncing serta memiliki pertulangan daun sejajar. Morfometri pada varietas Mapan 05 diperoleh data bahwa rata-rata helai daun 5-6 helai per-batang, rata-rata panjang daun $39,7 \mathrm{~cm}$, daun berwarna hijau muda, daun berbentuk bangun pita, permukaan daun kasar, tepi daun rata dan ujung daun 
Morfometri Beberapa Varietas Tanaman.., Tedy Sigit Purwansyah, Dewi Rosanti, Trimin Kartika, Indobiosains, Volume 3 No. 2, Agustus 2021, 28-38

meruncing serta memiliki pertulangan daun sejajar. Sedangkan varietas Ciasem, IR 64, IR 42, Inpari $32 \mathrm{HDB}$, Ketan hitam banyak memiliki kesamaan yaitu daun berwarna hijau, memiliki rata-rata jumlah daun perbatang 4-5 helai, daun berbentuk bangun pita, permukaan daun kasar, tepi daun rata dan ujung daun meruncing serta memiliki pertulangan daun sejajar. Pada varietas Ciasem memiliki rata-rata panjang daun $55,1 \mathrm{~cm}$, IR 42 rata-rata panjang daun 54,7 $\mathrm{cm}$, Inpari $32 \mathrm{HDB}$ memiliki rata-rata panjang daun 40,8 cm, serta ketan hitam memiliki panjang daun $31,5 \mathrm{~cm}$. Perbedaan warna daun menunjukkan adanya perbedaan kandungan pigmen daun termasuk pigmen klorofil, yaitu pada daun yang berwarna hijau tua mengandung klorofil lebih tinggi dibandingkan dengan daun yang bewarna hijau muda atau hijau kekuningan (Munawaroh et al., 2016).

\section{Morfometri Malai}

Morfometri malai yang diamati adalah jumlah malai per-batang, rata-rata panjang malai, serta rata-rata jumlah buah permalai. Adapun hasil pengamatan disajikan dalam Tabel 5. sebagai berikut:

Tabel 5. Morfometri Malai Dari Beberapa Varietas Tanaman Padi

\begin{tabular}{llccc}
\hline No. & $\begin{array}{c}\text { Nama } \\
\text { Varietas }\end{array}$ & $\begin{array}{c}\text { M/B } \\
\text { (Malai) }\end{array}$ & $\begin{array}{c}\bar{X} \mathbf{P M} \\
(\mathbf{C m})\end{array}$ & $\begin{array}{c}\bar{X} \mathbf{B} / \mathbf{M} \\
\text { Buah) }\end{array}$ \\
\hline 1. & Ciherang & 1 & 21,9 & 155 \\
2. & Cimelati & 1 & 27 & 169 \\
3. & Ciasem & 1 & 30 & 170 \\
4. & IR 64 & 1 & 22,3 & 87 \\
5. & IR 42 & 1 & 27,7 & 218 \\
6. & Inpari 32 HDB & 1 & 23 & 133 \\
7. & Mapan 05 & 1 & 26,3 & 156 \\
8. & Ketan Hitam & 1 & 21,1 & 90 \\
\hline
\end{tabular}

Keterangan: M/B (malai) = jumlah malai per-batang; $\bar{X} \mathrm{PM}(\mathrm{cm})=$ Rata-rata panjang malai; $\bar{X}$ B/M (buah) = Rata-rata buah per-malai. 
Dari hasil pengamatan morfologi malai dari kedelapan varietas tanaman padi didapatkan bahwa morfometri malai pada setiap varietas tanaman padi mempunyai kesamaan yaitu pada setiap satu batang terdiri dari satu malai. Perbedaan terdapat pada rata-rata panjang malai dan rata-rata jumlah buah permalai. Rata-rata panjang malai yang paling besar adalah varietas Ciasem yaitu $30 \mathrm{~cm}$ dibandingkan dengan varietas Ciherang 21,9 cm, varietas Cimelati 27 $\mathrm{cm}$, varietas IR $6422,3 \mathrm{~cm}$, varietas IR $4227,7 \mathrm{~cm}$, varietas Inpari 32 HDB 23 $\mathrm{cm}$, Mapan 05 26,3 cm, dan jumlah panjang malai terendah pada Ketan hitam yaitu: $21,1 \mathrm{~cm}$. Jumlah rata-rata buah per-malai yang terbesar terdapat pada varietas IR 42 yaitu 218 buah dan yang terkecil terdapat pada varietas IR 64 yaitu 87 buah.
Pada Tabel 5. didapat bahwa panjang malai pada setiap varietas dapat mempengaruhi jumlah buah permalai. Donggulo et al. (2017) dan Aribawa (2012) juga menyatakan bahwa panjang malai juga mempengaruhi jumlah gabah per-malai yang diperoleh. Semakin panjang malai yang terbentuk semakin banyak peluang gabah yang dapat ditampung oleh malai.

\section{Morfometri Buah/gabah}

Morfometri buah/gabah yang diamati yaitu bentuk buah, rata-rata diameter buah, rata-rata panjang buah, jumlah rata-rata berat buah, serta warna gabah. Adapun hasil pengamatan disajikan dalam Tabel 6. sebagai berikut:

Tabel 6. Morfologi Buah Dari Beberapa Varietas Tanaman Padi

\begin{tabular}{|c|c|c|c|c|c|c|}
\hline No. & $\begin{array}{l}\text { Nama } \\
\text { Varietas }\end{array}$ & BB & $\begin{array}{c}\bar{X} \text { DB } \\
(\mathbf{m m})\end{array}$ & $\begin{array}{l}\bar{X} \text { PB } \\
(\mathbf{m m})\end{array}$ & $\bar{X} \mathbf{B B}$ (g) & WG \\
\hline 1. & Ciherang & $\begin{array}{l}\text { Ramping } \\
\text { panjang }\end{array}$ & 2,5 & 9,4 & 1,44 & Kuning bersih \\
\hline 2. & Cimelati & Ramping & 2,6 & 10,3 & 1,49 & Kuning bersih \\
\hline 3. & Ciasem & Sedang panjang & 2,5 & 9,9 & 1,26 & Kuning bersih \\
\hline 4. & IR 64 & $\begin{array}{l}\text { Ramping } \\
\text { panjang }\end{array}$ & 2,6 & 9,5 & 1,37 & Kuning bersih \\
\hline 5. & IR 42 & Ramping & 2,6 & 7,9 & 1,11 & Kuning bersih \\
\hline 6. & Inpari $32 \mathrm{HDB}$ & Sedang & 2,6 & 9,5 & 1,44 & Kuning bersih \\
\hline 7. & Mapan 05 & Ramping & 2,5 & 10 & 1,48 & Kuning bersih \\
\hline 8. & Ketan Hitam & $\begin{array}{l}\text { Ramping } \\
\text { pendek }\end{array}$ & 2,8 & 9 & 1,47 & $\begin{array}{l}\text { Hitam keabu- } \\
\text { abuan }\end{array}$ \\
\hline
\end{tabular}

Keterangan: BB: Bentuk buah; $\bar{X} \mathrm{DB}(\mathrm{mm})=$ Rata-rata diameter buah; $\bar{X} \mathrm{~PB}(\mathrm{~mm})=$ Rata- rata panjang buah; $\bar{X}$ BB $(\mathrm{g})=$ Rata-rata berat buah; WG= Warna gabah.

Dari hasil penelitian morfologi buah pada beberapa varietas tanaman padi didapatkan bahwa morfologi buah pada setiap varietas tanaman padi mempunyai banyak perbedaan yang terdapat pada bentuk buah, diameter buah, panjang buah, berat buah, serta warna gabah pada setiap varietas.
Bentuk buah padi varietas Ciherang dan IR 64 Ramping panjang, pada varietas Cimelati, IR 42, mapan 05 memiliki bentuk buah Ramping, pada varietas Ciasem memiliki bentuk buah sedang panjang, varietas Inpari 32 memiliki bentuk buah sedang, serta pada varietas Ketan hitam berbentuk ramping pendek. 
Diameter rata-rata buah padi yang terbesar terdapat pada varietas Ketan hitam yaitu sebesar $2,8 \mathrm{~mm}$, sedangkan varietas Ciherang, Ciasem, Mapan 05 memiliki persamaan dengan ukuran ratarata diameter buah $2,5 \mathrm{~cm}$, pada varietas Cimelati, IR 64, IR 42, Inpari 32 HDB memiliki rata-rata diameter buah 2,6 $\mathrm{mm}$.Selain itu, pada hasil rata-rata bobot 50 buah padi dari kedelapan varietas padi tersebut varietas Cimelati memiliki nilai rata-rata bobot yang paling tinggi yaitu 1,49 gram berbanding sedikit dengan varietas Mapan 05 yang memiliki ratarata bobot 1,48 gram.

Nilai rata-rata bobot pada 50 butir gabah berhubungan dengan tinggi tanaman dan umur tanaman. Hal ini sesuai dengan hasil penelitian Fitri dan Handoyo (2019) bahwa postur padi yang tinggi cenderung menunjukkan umur tanaman yang semakin lama, sehingga periode pengisian bulirnya juga semakin lama yang kemudian membuat bobot gabahnya semakin berat. Postur tanaman yang tinggi menandakan semakin banyak fotosintat yang dihasilkan sehingga akan mempengaruhi bobot gabah karena mempunyai malai yang panjang dan gabah yang lebih banyak.

Warna pada padi varietas Ciherang, Cimelati, IR 64, IR 42 mempunyai kesamaan yaitu berwana kuning bersih, padi varietas Ciasem memiliki warna gabah kuning gelap, padi varietas Inpari $32 \mathrm{HDB}$ dan Mapan 05 memiliki warna gabah kuning terang, sedangkan pada padi varietas ketan hitam memiliki warna hitam keabu-abuan. Menurut Fitri dan Handoyo (2019) karakteristik warna gabah merupakan variabel pengamatan kualitatif yang memberikan ciri khas setiap varietas atau kultivarnya. Perbedaan warna gabah pada beras dipengaruhi berbagai faktor, salah satunya kadar antosianin yang terkandung di dalamnya.

\section{KESIMPULAN}

Morfometri beberapa varietas tanaman padi yang ditemukan di Kecamatan Pulau Rimau Kabupaten Banyuasin yaitu:

1. Sistem perakaran serabut, rata-rata jumlah cabang akar dalam satu batang varietas tanaman padi berkisar $41-80$ cabang akar.

2. Batang berjenis batang rumput (calmus) berbentuk bulat berongga dan beruas. Rata-rata ruas batang berkisar 4 - 6 ruas per-batang. Ratarata tinggi batang berkisar 59,8 - 106,2 $\mathrm{cm}$. Rata-rata diameter batang berkisar $0,54 \mathrm{~mm}-0,74 \mathrm{~mm}$.

3. Daun memiliki circum scriptio berbentuk pita berwarna hijau, dengan rata-rata jumlah daun berkisar $4-6$ helai, rata-rata panjang daun berkisar $31,5 \mathrm{~cm}-55,1 \mathrm{~cm}$, permukaan daun kasar, tepi daun rata, ujung daun meruncing dan pertulangan daun sejajar.

4. Malai berjumlah 1 per-batang, dengan rata-rata panjang malai berkisar 21,1 $30 \mathrm{~cm}$, dan rata-rata buah per-malai berkisar 87 - 218 buah.

5. Buah berbentuk ramping panjang, ramping, sedang panjang, sedang, sampai ramping pendek, berwarna kuning bersih hingga berwarna hitam keabu-abuan, dengan rata-rata diameter 25 - $28 \mathrm{~mm}$, rata-rata Panjang 7,9 - 10,3 mm, dan rata-rata berat buah 1,11 - 1,49 gram.

\section{DAFTAR PUSTAKA}

Akmaliyanti, D.D. 2008. Morfologi Beberapa Varietas Tanaman Padi (oryza sativa L.) Di Kecamatan Buai Pemuka Peliung Kabupaten Ogan Komering Ulu Timur. Skripsi. Fakultas Matematika Dan Ilmu Pengetahuan alam Universitas PGRI Palembang. 
Aribawa, 2012. Pengaruh Sistem Tanam Terhadap Peningkatan Produktivitas Padi Di Lahan Sawah Dataran Tinggi Beriklim Basah. Balai Pengkajian Teknologi Pertanian (BPTP) Bali. Denpasar.

Badan Penelitian dan Pengembangan Pertanian, 2017. Deskripsi Varietas Unggul Padi. Kementrian Pertanian.

Badan Pusat Statistik. 2015. Produksi Tanaman Bahan Makanan di Sumatera Selatan. Badan Pusat Statistik Provinsi Sumatera Selatan. ISSN/ISBN : 979-470-120-3, BPS : 5201005.16 .

Darwati, E. dan Noeriwan 2019. Keragaan Hasil VUB Padi Inpari 42, 43, 32 dan Varietas Existing Ciherang di KP. Mojosari.

Donggulo, C. V., Lapanjang, I. M., dan Made, U. 2017. Pertumbuhan Dan Hasil Tanaman Padi (Oryza sativa L) Pada Berbagai Pola Jajar Legowo Dan Jarak Tanam. Agroland: Jurnal Ilmu-ilmu Pertanian, 24(1): 27-35.

Fitri, I. G. S., danHandoyo, T. 2019. Identifikasi Karakteristik Morfologi Dan Molekuler 21 Varietas Padi Aromatik (Oryza sativa L.) Berdasarkan Penanda RAPD (Random Amplified Polymorphic DNA). Berkala Ilmiah Pertanian, Vol 2(2), 72-76 hal.

Gani, A.R.F., dan Arwita, W. 2020. Kecenderungan Literasi Informasi Mahasiswa Baru Pada Mata Kuliah Morfologi Tumbuhan. Jurnal Pelita Pendidikan, 8(2): 145-150.
Kesmayanti, N.dan Mareza, E. 2014. Identifikasi Karakter AgroMorfologi Varietas Padi (Oryza sativa L.) Potensi Lahan Pasang Surut. Fakultas Pertanian. Universitas IBA. Jurnal Ilmiah AgrIBA. No. 2.

Lestari, P., Susilowati, D. N., \& Riyanti, E. I. 2019. Pengaruh Hormon Asam Indol Asetat Yang Dihasilkan Azospirillum sp. Terhadap Perkembangan Akar Padi. Jurnal AgroBiogen 3(2):6672.

Munawaroh, L., Sulistyono, E., dan Lubis, I. 2016. Karakter Morfologi Dan Fisiologi Yang Berkaitan Dengan Efisiensi Pemakaian Air Pada Beberapa Varietas Padi Gogo. Jurnal Agronomi Indonesia (Indonesian Journal of Agronomy), 44(1), 1-7.

Norsalis, E. 2011. Padi Sawah Dan Padi Gogo Tinjauan Secara Morfologi, Budidaya dan Fisiologi. Nusa tenggara.

Rosanti, D. 2013. Morfologi Tumbuhan. Erlangga. Jakarta.

Sutrisna, I. K., dan Dewi, M. K. 2016. Pengaruh Tingkat Produksi, Harga Dan Konsumsi Terhadap Impor Bawang Merah Di Indonesia. EJurnal Ekonomi Pembangunan Universitas Udayana, 5(1).

Zaeroni, R. dan Rustariyuni, S. D. 2016. Pengaruh Produksi Beras, Konsumsi Dan Cadangan Devisa Terhadap Impor Beras Di Indonesia. E-Jurnal Ekonomi Pembangunan Universitan Udayana. 5(9). 